\title{
Lithium Insertion Chemistry of Some Iron Vanadates
}

\author{
Sébastien Patoux and Thomas J. Richardson* \\ Environmental Energy Technologies Division, \\ Lawrence Berkeley National Laboratory, \\ Berkeley, California 94720, USA
}

\begin{abstract}
Lithium insertion into various iron vanadates has been investigated. $\mathrm{Fe}_{2} \mathrm{~V}_{4} \mathrm{O}_{13}$ and $\mathrm{Fe}_{4}\left(\mathrm{~V}_{2} \mathrm{O}_{7}\right)_{3} \cdot 3 \mathrm{H}_{2} \mathrm{O}$ have discharge capacities approaching $200 \mathrm{mAh} / \mathrm{g}$ above $2.0 \mathrm{~V}$ vs. $\mathrm{Li}^{+} / \mathrm{Li}$. Although the potential profiles change significantly between the first and subsequent discharges, capacity retention is unexpectedly good. Other phases, structurally related to $\mathrm{FeVO}_{4}$, containing copper and/or sodium ions were also studied. One of these, $\beta-\mathrm{Cu}_{3} \mathrm{Fe}_{4}\left(\mathrm{VO}_{4}\right)_{6}$, reversibly consumes almost 10 moles of electrons per formula unit (ca. $240 \mathrm{mAh} \mathrm{g}^{-1}$ ) between 3.6 and $2.0 \mathrm{~V}$ vs. $\mathrm{Li}^{+} / \mathrm{Li}$, in a non-classical insertion process. It is proposed that both copper and vanadium are electrochemically active, whereas iron(III) reacts to form $\mathrm{LiFe}^{\mathrm{III}} \mathrm{O}_{2}$. The capacity of the $\mathrm{Cu}_{3} \mathrm{Fe}_{4}\left(\mathrm{VO}_{4}\right)_{6} / \mathrm{Li}$ system is nearly independent of cycling rate, stabilizing after a few cycles at $120-140 \mathrm{mAh} \mathrm{g}^{-1}$. Iron vanadates exhibit better capacities than their phosphate analogues, whereas the latter display more constant discharge potentials.
\end{abstract}

* Corresponding author; E-mail: tjrichardson@lbl.gov

Keywords: Lithium batteries, iron vanadates, insertion compounds 


\section{Introduction}

As alternatives to the presently used positive electrode materials for lithium batteries, (mostly layered $\mathrm{LiCoO}_{2}$-type and spinel $\mathrm{LiMn}_{2} \mathrm{O}_{4}$ ), numerous polyanionic compounds have been studied. Covering a very large range of compositions, these materials generally benefit from the polyanion inductive effect that increases the redox potential of the transition metal compared to that in simple oxides [1]. Following the seminal publication of Padhi et al. [2], polyanionic frameworks associated with different transition metal elements have been considered. Among these, $\mathrm{LiFePO}_{4}$ presents the most promising electrochemical performance, with safety, stability and cost advantages over the layered cobalt and nickel oxides [3]. Much attention was also given to Nasicon and anti-Nasicon phosphate $[4,5]$ and sulfate $[6,7]$ structures containing iron and vanadium. The most interesting materials comprise iron(III), titanium(IV), vanadium(V, III), and to a lesser degree, manganese(II, III, IV), niobium(V) and copper(II) [8]. Vanadate groups $\mathrm{VO}_{4}{ }^{3-}$ and $\mathrm{V}_{2} \mathrm{O}_{7}^{4-}$ behave structurally like $\mathrm{PO}_{\mathrm{x}}$ and $\mathrm{SO}_{\mathrm{x}}$ polyanions, but vanadium may be electrochemically active, and therefore may contribute to theoretical capacity (Table 1).

In this context, we decided to investigate some iron(III) vanadates. $\mathrm{FeVO}_{4}$ (type I) and $\mathrm{Fe}_{2} \mathrm{~V}_{4} \mathrm{O}_{13}$ are the two stable compounds in the $\mathrm{Fe}_{2} \mathrm{O}_{3}-\mathrm{V}_{2} \mathrm{O}_{5}$ binary diagram. Lithium insertion at low potentials in $\mathrm{FeVO}_{4} \cdot \mathrm{nH}_{2} \mathrm{O}$ and $\mathrm{Fe}_{2} \mathrm{~V}_{4} \mathrm{O}_{13} \cdot \mathrm{nH}_{2} \mathrm{O}$ were investigated by the Tarascon group [9, 10], but their reversibility at higher potentials was not studied at that time. To our knowledge, insertion of lithium into $\mathrm{Fe}_{4}\left(\mathrm{~V}_{2} \mathrm{O}_{7}\right) \cdot 3 \mathrm{H}_{2} \mathrm{O}, \quad \beta-\mathrm{Cu}_{3} \mathrm{Fe}_{4}\left(\mathrm{VO}_{4}\right)_{6}$ and $\mathrm{NaCuFe}_{2}\left(\mathrm{VO}_{4}\right)_{3}$ has not previously been reported. Here we discuss the lithium insertion chemistry of five iron(III)vanadium(V) complex oxides in the range from 3.6 to $2.0 \mathrm{~V}$ vs. $\mathrm{Li}^{+} / \mathrm{Li}$, in which vanadium is electrochemically active, while iron is partly or totally inactive. 


\section{Experimental}

$\mathrm{FeVO}_{4}$ and $\mathrm{Fe}_{2} \mathrm{~V}_{4} \mathrm{O}_{13}$ were prepared by mixing stoichiometric amounts of ammonium metavanadate and iron(III) nitrate in water with sufficient hydrochloric acid added to complete dissolution. After drying at $90^{\circ} \mathrm{C}$, the mixtures were fired at $500^{\circ} \mathrm{C}$ for $60 \mathrm{~h}$ in the case of $\mathrm{FeVO}_{4}$, and at $500^{\circ} \mathrm{C}(18 \mathrm{~h})$ and $600^{\circ} \mathrm{C}(60 \mathrm{~h})$ for $\mathrm{Fe}_{2} \mathrm{~V}_{4} \mathrm{O}_{13} \cdot \mathrm{Fe}_{4}\left(\mathrm{~V}_{2} \mathrm{O}_{7}\right)_{3} \cdot 3 \mathrm{H}_{2} \mathrm{O}$ was synthesized at the Laboratoire de Réactivité et Chimie des Solides (Amiens, France) by Dr. Philippe Poizot, by direct precipitation from aqueous solution (i.e.; "chimie douce" method), as reported elsewhere [11]. Two batches of $\beta-\mathrm{Cu}_{3} \mathrm{Fe}_{4}\left(\mathrm{VO}_{4}\right)_{6}$ were prepared, but the one prepared from a mixture of $\mathrm{CuO}, \mathrm{Fe}_{2} \mathrm{O}_{3}, \mathrm{~V}_{2} \mathrm{O}_{5}$, heated at $500^{\circ} \mathrm{C}(14 \mathrm{~h})$ and $700^{\circ} \mathrm{C}(60 \mathrm{~h})$, contained minor unidentified impurities. The second batch, starting with an aqueous solution of copper sulfate, iron(III) nitrate, ammonium metavanadate and hydrochloric acid, which allowed a better homogenization of the precursors, then dried and fired at $500^{\circ} \mathrm{C}(72 \mathrm{~h})$ and $600^{\circ} \mathrm{C}(20 \mathrm{~h})$, was phase pure. $\mathrm{NaCuFe}_{2}\left(\mathrm{VO}_{4}\right)_{3}$ was prepared following the same procedure but adding sodium nitrate, and firing at $500^{\circ} \mathrm{C}(36 \mathrm{~h})$ and $600^{\circ} \mathrm{C}(60 \mathrm{~h})$.

Iron(III) phosphates were also synthesized for comparison with the iron(III) vanadates. $\mathrm{Fe}\left(\mathrm{PO}_{3}\right)_{3}, \mathrm{Fe}_{3} \mathrm{O}_{3} \mathrm{PO}_{4}, \alpha-\mathrm{FePO}_{4}$, and $\mathrm{Fe}_{4}\left(\mathrm{P}_{2} \mathrm{O}_{7}\right)_{3}$ were prepared by dissolving stoichiometric amounts of iron(III) nitrate and hydrogen ammonium phosphate in water, drying and firing at $600^{\circ} \mathrm{C}, 600^{\circ} \mathrm{C}, 800^{\circ} \mathrm{C}$ and $800^{\circ} \mathrm{C}$, respectively. $\mathrm{Fe}_{1.2} \mathrm{PO}_{4} \mathrm{X}\left(\mathrm{X}=\mathrm{F}_{0.11}(\mathrm{OH})_{0.46}\left(\mathrm{H}_{2} \mathrm{O}\right)_{0.43}\right)$ was made by hydrothermal synthesis following ref. 12, but with a shorter reaction time $\left(24 \mathrm{~h}\right.$ at $\left.200^{\circ} \mathrm{C}\right)$. $\mathrm{FePO}_{4}$ (heterosite) was synthesized by chemical extraction of lithium $\left(\mathrm{NO}_{2} \mathrm{BF}_{4}\right.$ in acetonitrile) from synthetic triphylite, $\mathrm{LiFePO}_{4}[13]$. 
X-ray diffraction (XRD) patterns were collected at ambient temperature using a Philips X'Pert diffractometer $\left(\theta-\theta\right.$ geometry, diffracted beam monochromator) with $\mathrm{CuK}_{\alpha}$ radiation. Lattice parameters were determined by full pattern fitting using the WinPLOTR/Fullprof suite [14]; those of the iron vanadates are reported in Table 2.

Composite electrodes were prepared by first thoroughly mixing the active material ( 83.3 w/o) with carbon black $(16.7 \mathrm{w} / \mathrm{o})$ for $30 \mathrm{~min}$ in a planetary ball mill. Polyvinylidene difluoride (Kynar 741) dissolved in N-methyl-pyrrolidone was then added to the mixture to give $70 \mathrm{w} / \mathrm{o}$ of active material in the final mixture, which was applied to aluminum foil by doctor blade. Electrodes $\left(1.8 \mathrm{~cm}^{2}\right.$ discs $)$ with loadings $\sim 8 \mathrm{mg}$ of AM active material per $\mathrm{cm}^{2}$ were dried for $24 \mathrm{~h}$ at room temperature and then for $24 \mathrm{~h}$ at $120^{\circ} \mathrm{C}$ under vacuum. Type 2032 coin cells were assembled in a helium filled dry box $\left(<1 \mathrm{ppm} \mathrm{O}_{2} / \mathrm{H}_{2} \mathrm{O}\right)$ using Li metal foil counter electrodes and Celgard 3401 separators saturated with $1 \mathrm{M} \mathrm{LiPF}_{6}$ in ethylene carbonate/dimethylcarbonate (1:2 w:w). Lithium insertion/extraction was monitored with a MacPile II cycling system operating in galvanostatic mode.

\section{Results}

Depending on the synthesis conditions, four allotropic forms of $\mathrm{FeVO}_{4}$ can be prepared [15]. The lowest density form, type I, is the one prepared under atmospheric pressure, and is closely related to $\beta-\mathrm{Cu}_{3} \mathrm{Fe}_{4}\left(\mathrm{VO}_{4}\right)_{6}$, as discussed later. $\mathrm{FeVO}_{4}$-I was first isolated by Levinson et al. [16], and its crystal structure was reported by Robertson et al. [17]. The structure consists of a 3-D packing of $\mathrm{VO}_{4}$ tetrahedra, $\mathrm{FeO}_{6}$ octahedra and $\mathrm{FeO}_{5}$ trigonal bipyramids. The three independent iron atoms, two in distorted octahedra and one in a distorted trigonal bipyramid, are joined by $\mathrm{VO}_{4}$ tetrahedra to create a doubly bent chain of six edge-sharing polyhedra. The 
structure of $\mathrm{Fe}_{2} \mathrm{~V}_{4} \mathrm{O}_{13}$, a compound simultaneously prepared by Baudrin et al. [18] and Wang et al. [19], was described by the latter group. It is built up from isolated edge-shared $\mathrm{Fe}_{2} \mathrm{O}_{10}$ octahedral dimers and $\mathrm{U}$-shaped tetrapolyvanadate $\mathrm{V}_{4} \mathrm{O}_{13}{ }^{6-}$ anions (comprising four cornershared tetrahedra). Poizot et al. recently published a complete binary phase diagram for the $\mathrm{Fe}_{2} \mathrm{O}_{3}-\mathrm{V}_{2} \mathrm{O}_{5}$ system [11], which contains the two well-known definite compositions $\mathrm{Fe}_{2} \mathrm{~V}_{4} \mathrm{O}_{13}$ and $\mathrm{FeVO}_{4}$, plus two metastable compounds, $\mathrm{Fe}_{4} \mathrm{~V}_{6} \mathrm{O}_{21}$ [or $\mathrm{Fe}_{4}\left(\mathrm{~V}_{2} \mathrm{O}_{7}\right)_{3}$ ] and $\mathrm{FeV}_{3} \mathrm{O}_{9}$ [or $\left.\mathrm{Fe}\left(\mathrm{VO}_{3}\right)_{3}\right]$. These authors discussed in detail the preparation, by direct precipitation from aqueous solution, of hydrated iron(III) vanadates $(\mathrm{V})$, which become anhydrous and crystalline after controlled heating. The structure of $\mathrm{Fe}_{4} \mathrm{~V}_{6} \mathrm{O}_{21} \cdot 3 \mathrm{H}_{2} \mathrm{O}$ has been determined [20], but that of $\mathrm{FeV}_{3} \mathrm{O}_{9} \cdot \mathrm{nH}_{2} \mathrm{O}$ remains unknown. Although the $\mathrm{H}$ atoms were not clearly located, $\mathrm{Fe}_{4} \mathrm{~V}_{6} \mathrm{O}_{21} \cdot 3 \mathrm{H}_{2} \mathrm{O}$ is more accurately written as $\mathrm{Fe}_{2}\left(\mathrm{H}_{2} \mathrm{O}\right)\left[\mathrm{V}_{2} \mathrm{O}_{7} \cdot \mathrm{VO}_{3}(\mathrm{OH})\right]$ to take into account the presence of these distinct structural units. Two vanadate ions are present; a divanadate $\mathrm{V}_{2} \mathrm{O}_{7}{ }^{4-}$ and a vanadate $\mathrm{VO}_{4}{ }^{3-}$ or $\mathrm{VO}_{3}(\mathrm{OH})^{2-}$. The two different $\mathrm{FeO}_{6}$ octahedra share an edge.

Insertion of lithium into $\mathrm{FeVO}_{4}$ and $\mathrm{FeVO}_{4} \cdot \mathrm{nH}_{2} \mathrm{O}$ has been studied recently, particularly its insertion capacity, which depends upon the water content [21, 22, 23]. At low potential, the host structure collapses and the $\mathrm{Fe}^{3+}$ ions are reduced to Fe metal. Hayashibara et al. [24] also investigated the insertion of lithium into $\mathrm{FeVO}_{4}$ by chemical reduction. The electrochemical behavior under GITT conditions of $\mathrm{FeVO}_{4}, \mathrm{Fe}_{2} \mathrm{~V}_{4} \mathrm{O}_{13}$ and $\mathrm{Fe}_{4}\left(\mathrm{~V}_{2} \mathrm{O}_{7}\right)_{3} \cdot 3 \mathrm{H}_{2} \mathrm{O}$ are shown in Fig. 1. All three materials exhibit smooth, sloping discharge profiles, with some plateau-like features for $\mathrm{Fe}_{2} \mathrm{~V}_{4} \mathrm{O}_{13} . \mathrm{FeVO}_{4}$, which has the highest $\mathrm{Fe} / \mathrm{V}$ ratio, has the lowest capacity and the poorest capacity retention in the first cycle ( $\sim 60 \%$ of the initial discharge capacity is not recovered). In contrast, the reversibility is good for the $\mathrm{Fe}_{2} \mathrm{~V}_{4} \mathrm{O}_{13} / \mathrm{Li}$ and $\mathrm{Fe}_{4}\left(\mathrm{~V}_{2} \mathrm{O}_{7}\right)_{3} \cdot 3 \mathrm{H}_{2} \mathrm{O} / \mathrm{Li}$ systems, although the charge profiles differ significantly from their initial discharges. These compounds have lower 
$\mathrm{Fe} / \mathrm{V}$ ratios and higher capacities than $\mathrm{FeVO}_{4}: 160 \mathrm{mAh} / \mathrm{g}$ for $\mathrm{FeVO}_{4}(\mathrm{Fe} / \mathrm{V}=1), 193 \mathrm{mAh} / \mathrm{g}$ for $\mathrm{Fe}_{4}\left(\mathrm{~V}_{2} \mathrm{O}_{7}\right)_{3} \cdot 3 \mathrm{H}_{2} \mathrm{O}(\mathrm{Fe} / \mathrm{V}=0.67)$ and $205 \mathrm{mAh} / \mathrm{g}$ for $\mathrm{Fe}_{2} \mathrm{~V}_{4} \mathrm{O}_{13}(\mathrm{Fe} / \mathrm{V}=0.5)$. Thus the theoretical capacities corresponding to the $\mathrm{V}^{5+} / \mathrm{V}^{4+}$ redox couple give the same trend as the experimental values, whereas the $\mathrm{Fe}^{3+} / \mathrm{Fe}^{2+}$ redox couple would lead to an opposite trend, and both redox couples active together would provide an intermediate situation (Table 1). The amount of lithium inserted into the three materials approximately corresponds to the complete reduction of $\mathrm{V}(\mathrm{V})$ to $\mathrm{V}(\mathrm{IV})$, with low activity of $\mathrm{Fe}(\mathrm{III})$, as we discuss later in the case of $\beta-\mathrm{Cu}_{3} \mathrm{Fe}_{4}\left(\mathrm{VO}_{4}\right)_{6}$. However, the situation is actually more complex for all the three compounds, especially for $\mathrm{FeVO}_{4}$. According to the ${ }^{57} \mathrm{Fe}$ Mössbauer study of Denis et al. [22] performed on the $\mathrm{FeVO}_{4} / \mathrm{Li}$ system, only the iron would be reduced when the composition " $\mathrm{LiFeVO}_{4}$ " is reached. This is nevertheless not in agreement with the conclusions of Hayashibara et al. [24], who proposed a two step process to reach the composition $\mathrm{x}=1$ in $" \mathrm{Li}_{\mathrm{x}} \mathrm{FeVO}_{4}$ ": 1) insertion of lithium into $\mathrm{Li}_{\mathrm{x}} \mathrm{FeVO}_{4}$ from $\mathrm{x}=0$ to $\mathrm{x}=1 / 3$, and 2) decomposition into $\mathrm{Li}_{1 / 3} \mathrm{FeVO}_{4}, \mathrm{LiFeO}_{2}$ and $\mathrm{VO}_{2}$ from $\mathrm{x}=1 / 3$ to $\mathrm{x}=1$. From a practical perspective, $\mathrm{Fe}_{2} \mathrm{~V}_{4} \mathrm{O}_{13} / \mathrm{Li}$ presents the best capacity retention among the three systems, although the original discharge profile is never recovered in cycling (Fig. 2).

We looked at the behavior of the structurally related compounds $\beta-\mathrm{Cu}_{3} \mathrm{Fe}_{4}\left(\mathrm{VO}_{4}\right)_{6}$ and $\mathrm{NaCuFe}_{2}\left(\mathrm{VO}_{4}\right)_{3}$, both having a $\mathrm{Fe} / \mathrm{V}$ ratio of 0.67 (i.e.; lower than for $\mathrm{FeVO}_{4}$ ), as in $\mathrm{Fe}_{4}\left(\mathrm{~V}_{2} \mathrm{O}_{7}\right)_{3} \cdot 3 \mathrm{H}_{2} \mathrm{O}$. Lafontaine et al. [25] discussed the structural relationships between $\beta-\mathrm{Cu}_{3} \mathrm{Fe}_{4}\left(\mathrm{VO}_{4}\right)_{6}$ and several other vanadates, phosphates and molybdates of general formula $\mathrm{A}_{\mathrm{x}} \mathrm{B}_{\mathrm{y}}\left(\mathrm{VO}_{4}\right)_{6}$, e.g. $\mathrm{NaCuFe}_{2}\left(\mathrm{VO}_{4}\right)_{3}, \mathrm{FeVO}_{4}, \mathrm{ZnMoO}_{4}$, and $\mathrm{Mg}_{3} \mathrm{Ti}_{4}\left(\mathrm{PO}_{4}\right)_{6} \cdot \beta-\mathrm{Cu}_{3} \mathrm{Fe}_{4}\left(\mathrm{VO}_{4}\right)_{6}$, which is different from the mineral lyonsite (similar composition), crystallizes in the same structure as the mineral howardevansite, $\mathrm{NaCuFe}_{2}\left(\mathrm{VO}_{4}\right)_{3}$, as does the synthetic form of the latter. Their similar polyhedral arrangement is built up by edge sharing $\mathrm{Fe}_{2} \mathrm{~V}_{10}$ entities, corner-linked by $\mathrm{VO}_{4}$ 
tetrahedra to form sheets, and also chains of $\mathrm{Fe}_{2} \mathrm{~V}_{8}$ dimers, the whole thus delimiting cavities to host $\mathrm{Cu}^{2+}$ and $\mathrm{Na}^{+}$ions. Figure 3 reproduces the framework of these two $\mathrm{Fe}_{4}(\mathrm{VO})_{6}$-type compounds, and the one of $\mathrm{Fe}_{6}\left(\mathrm{VO}_{4}\right)_{6}$ type (e.g.; $\left.\mathrm{FeVO}_{4}\right)$, which exhibit the same common basic unit, but differently linked. In the latter case, less space is available for guest ions due to the presence of additional $\mathrm{FeO}_{\mathrm{x}}$ polyhedra (i.e.; $\mathrm{FeO}_{5}$ trigonal bipyramids). Insertion of lithium into $\beta-\mathrm{Cu}_{3} \mathrm{Fe}_{4}\left(\mathrm{VO}_{4}\right)_{6}$ and $\mathrm{NaCuFe}_{2}\left(\mathrm{VO}_{4}\right)_{3}$ is presented in Figure 4. Both materials exhibited smooth, sloping profiles in discharge and charge, with good reversibility in the first cycle (excellent in the case of $\left.\beta-\mathrm{Cu}_{3} \mathrm{Fe}_{4}\left(\mathrm{VO}_{4}\right)_{6} / \mathrm{Li}\right)$, but the internal impedance was rather high. Large capacities in the first discharge down to $2 \mathrm{~V}$ were obtained, $193 \mathrm{mAh} / \mathrm{g}$ for the sodium compound and 220$243 \mathrm{mAh} / \mathrm{g}$ for $\beta-\mathrm{Cu}_{3} \mathrm{Fe}_{4}\left(\mathrm{VO}_{4}\right)_{6}$. Unfortunately, capacity decreased during cycling, as shown in Figure 5 for $\beta-\mathrm{Cu}_{3} \mathrm{Fe}_{4}\left(\mathrm{VO}_{4}\right)_{6} / \mathrm{Li}$. Surprisingly, changing the cycling rate had little effect on the cycling behavior. After about twenty cycles, the discharge capacities stabilized at 120$130 \mathrm{mAh} / \mathrm{g}$.

Ex situ X-ray diffraction experiments were performed on $\mathrm{Cu}_{3} \mathrm{Fe}_{4}\left(\mathrm{VO}_{4}\right)_{6} / \mathrm{Li}$ cells. Due to the numerous Bragg positions allowed by the triclinic system, and to decreased intensity signal as compared with the pristine material, we unable to fully refine the patterns collected during the first discharge and the subsequent charge. The XRD patterns collected from the fresh electrode, at the end of first discharge, at the end of first charge, and after 25 complete cycles, are shown in Figure 6. During the first discharge, it appears that either a new phase develops or the original phase reorganizes. Substantial amorphization takes place near the end of discharge, as all of the peaks corresponding to $\beta-\mathrm{Cu}_{3} \mathrm{Fe}_{4}\left(\mathrm{VO}_{4}\right)_{6}$ disappeared. Surprisingly, partial recrystallization occurred on the subsequent charge. The repetition of this amorphization/partial recrystallization process became less complete with cycling, and none of the initial material or related phases was 
recovered after a few cycles. The characteristic peaks of $\mathrm{Cu}$ metal $(\mathrm{Fm} 3 \mathrm{~m}, \mathrm{a} \sim 3.62 \AA)$ and a very small amount of $\mathrm{LiFeO}_{2}(\mathrm{Fm} 3 \mathrm{~m}, \mathrm{a} \sim 4.13 \AA)$ appeared at the end of the first discharge. The presence of metallic copper was also indicated by the red coloration of the electrode. These two phases disappeared on charging, but reappeared on the next discharge. Over 25 cycles, the amount of $\mathrm{LiFeO}_{2}$ substantially increased, while the metallic copper peaks weakened. The formation of $\mathrm{LiFeO}_{2}$ and $\mathrm{Cu}^{0}$ was concurrent with amorphization of $\beta-\mathrm{Cu}_{3} \mathrm{Fe}_{4}\left(\mathrm{VO}_{4}\right)_{6}$. Similarly, during the partial recrystallization of $\beta-\mathrm{Cu}_{3} \mathrm{Fe}_{4}\left(\mathrm{VO}_{4}\right)_{6}$ (i.e.; on charge), the reflections due to $\mathrm{LiFeO}_{2}$ and $\mathrm{Cu}$ vanished. Taking account of these observations, and being aware of the work performed on copper vanadates [26], iron vanadates [24] and several other copper polyanions [8], we conclude that $\beta-\mathrm{Cu}_{3} \mathrm{Fe}_{4}\left(\mathrm{VO}_{4}\right)_{6}$ probably first inserts lithium ions via a solid solution process, with partial reduction of $\mathrm{Fe}(\mathrm{III})$ and/or $\mathrm{V}(\mathrm{V})$ to $\mathrm{Fe}(\mathrm{II})$ and $\mathrm{V}(\mathrm{IV})$, respectively. Then, the structure collapses into $\mathrm{LiFeO}_{2}, \mathrm{Cu}^{0}$ and amorphous $\mathrm{VO}_{2}$. The overall reaction corresponds to the reduction of $\mathrm{Cu}^{2+}$ to $\mathrm{Cu}^{0}$ and $\mathrm{V}^{5+}$ to $\mathrm{V}^{4+}$, with iron formally inactive. During the subsequent charge, this process is partly reversed, similar to the behavior of $\mathrm{Cu}_{2.33} \mathrm{~V}_{4} \mathrm{O}_{11} / \mathrm{Li}$ [27], but with less efficient decomposition and recrystallization of the starting material. Note that the concomitant formation of $\mathrm{LiFeO}_{2}$, as reported in the case of $\mathrm{FeVO}_{4} / \mathrm{Li}$ [24], supports the previous observation concerning the minor electrochemical activity of $\mathrm{Fe}^{3+}$ in $\mathrm{Fe}_{2} \mathrm{~V}_{4} \mathrm{O}_{13}$ and other iron(III) vanadates.

\section{Discussion and conclusions}

As Poizot has shown [11], parallels exist between the chemistry of vanadates and phosphates. Four iron(III)-phosphorus(V) complex oxides, $\mathrm{Fe}\left(\mathrm{PO}_{3}\right)_{3}, \mathrm{Fe}_{3} \mathrm{O}_{3} \mathrm{PO}_{4}, \mathrm{FePO}_{4}$ and $\mathrm{Fe}_{4}\left(\mathrm{P}_{2} \mathrm{O}_{7}\right)_{3}$, are found in the binary $\mathrm{Fe}_{2} \mathrm{O}_{3}-\mathrm{P}_{2} \mathrm{O}_{5}$ [28]. Figure 7 shows the voltage-composition 
profiles for these compounds, along with the metastable $\mathrm{Fe}^{\mathrm{III}} \mathrm{PO}_{4}$-heterosite and $\mathrm{Fe}^{\mathrm{III}}{ }_{1.2} \mathrm{PO}_{4} \mathrm{X}$. The electrochemical properties of other iron(III) phosphates, either lithiated, such as $\mathrm{LiFePO}_{4}$ [3], A- and $\mathrm{B}-\mathrm{Li}_{3} \mathrm{Fe}_{2}\left(\mathrm{PO}_{4}\right)_{3}$ [29], $\mathrm{LiFeP}_{2} \mathrm{O}_{7}$ [30], or hydrated, such as the various forms of $\mathrm{FePO}_{4} \cdot \mathrm{xH}_{2} \mathrm{O}[31,32,33,34]$, and silicates/germinates $\mathrm{LiFeX}_{2} \mathrm{O}_{6}(\mathrm{X}=\mathrm{Ge}, \mathrm{Si})$ [8], $\mathrm{Li}_{2} \mathrm{FeSiO}_{4}$ [36], have also been reported, but are not discussed here. For most phosphates, reduction of $\mathrm{Fe}^{3+}$ into $\mathrm{Fe}^{2+}$ occurs at about $2.8 \mathrm{~V}$ vs. $\mathrm{Li}^{+} / \mathrm{Li}$. The $\mathrm{LiFePO}_{4} / \mathrm{FePO}_{4}$ system is a well-known exception, having a two-phase process at $3.45 \mathrm{~V}$, due to the structural rigidity of the olivine structure with edge sharing between $\mathrm{PO}_{4}$ and $\mathrm{FeO}_{6}$ polyhedra. For $\mathrm{Fe}\left(\mathrm{PO}_{3}\right)_{3} / \mathrm{Li}, \mathrm{Fe}_{3} \mathrm{O}_{3} \mathrm{PO}_{4} / \mathrm{Li}$ and $\mathrm{FePO}_{4}$-quartz/Li, the discharge capacity is very low; that of $\mathrm{Fe}_{4}\left(\mathrm{P}_{2} \mathrm{O}_{7}\right)_{3} / \mathrm{Li}$ is slightly better, but it is largely irreversible. The experimental capacity of $\mathrm{FePO}_{4}$-heterosite/Li is close to the theoretical value despite some kinetic limitations. $\mathrm{Fe}_{1.2} \mathrm{PO}_{4} \mathrm{X} / \mathrm{Li}$ has a large capacity and good rate behavior, but exhibits substantial polarization, especially on charging [12]. To our knowledge, its vanadium counterpart, $\mathrm{Fe}_{1.21} \mathrm{VO}_{4} \mathrm{X}$, has not been prepared. This hypothetical material might possibly combine the redox activities of both $\mathrm{V}^{5+} / \mathrm{V}^{4+}$ and $\mathrm{Fe}^{3+} / \mathrm{Fe}^{2+}$ couples (giving a theoretical capacity of about $340 \mathrm{mAh} / \mathrm{g}$ ).

The electrochemical properties of several other iron(III) polyanion compounds have been investigated during the past few years, as reported in Table 1. The capacity of A-Fe $2\left(\mathrm{MoO}_{4}\right)_{3}$ suffers from the high mass of Mo, but this material does have good electronic conductivity, and complete reduction/oxidation of $\mathrm{Fe}^{3+} / \mathrm{Fe}^{2+}$ is easily obtained along a nicely reversible plateau at $3.0 \mathrm{~V}$ vs. $\mathrm{Li}^{+} / \mathrm{Li}$. Both crystal types of $\mathrm{Fe}_{2}\left(\mathrm{SO}_{4}\right)_{3}$ exhibit two-phase process at $3.6 \mathrm{~V}$ vs. $\mathrm{Li}^{+} / \mathrm{Li}$, with performance still to be improved, particularly for prolonged cycling. The iron(III) borates have little or no capacity above $2 \mathrm{~V} \mathrm{vs.} \mathrm{Li}^{+} / \mathrm{Li}[35]$. 
In conclusion, iron vanadates generally have smooth sloping voltage profiles and higher experimental capacities than any of the other iron polyanion materials. They benefit from the electrochemical activity of $\mathrm{V}^{5+}$ in the polyanions, in contrast to phosphates, sulfates, molybdates and borates, into which $\mathrm{P}^{5+}, \mathrm{S}^{6+}, \mathrm{Mo}^{6+}$ and $\mathrm{B}^{3+}$ are inert. On the other hand, $\mathrm{Fe}^{3+}$ may be expelled from the vanadates in the form of $\mathrm{LiFeO}_{2}$. For $\beta-\mathrm{Cu}_{3} \mathrm{Fe}_{4}\left(\mathrm{VO}_{4}\right)_{6}$, and probably for $\mathrm{NaCuFe}_{2}\left(\mathrm{VO}_{4}\right)_{3}$, copper is also segregated as the metal. Application of spectroscopic techniques such as ${ }^{57} \mathrm{Fe}$ Mössbauer and EXAFS-XANES could give a better understanding of these unusual phenomena which seem to be unique to iron and/or copper vanadates.

\section{Acknowledgments}

This work was supported by the Assistant Secretary for Energy Efficiency and Renewable Energy, Office of FreedomCAR and Vehicle Technologies of the U. S. Department of Energy under Contract No. DE-AC02-05CH11231. The authors also thank Dr. Philippe Poizot for providing us with one of the compounds presented in this study.

\section{References}

[1] C. Masquelier, S. Patoux, C. Wurm, M. Morcrette, in A. Nazri, G.Pistoia (Eds.), Lithium batteries, Science \& Technology, Kluwer Academics, 2004, pp. 445-477.

[2] A.K. Padhi, PhD thesis, University of Texas at Austin (1997).

[3] A.K. Padhi, K.S. Nanjundaswamy and J.B. Goodenough, J. Electrochem. Soc., 144 (1997) 1188-1194.

[4] A.K. Padhi, K.S. Nanjundaswamy, C. Masquelier, S. Okada and J.B. Goodenough, J. Electrochem. Soc., 144 (1997) 1609-1613. 
[5] A.K. Padhi, K.S. Nanjundaswamy, C. Masquelier and J.B. Goodenough, J. Electrochem. Soc., 144 (1997) 2581-2586.

[6] A.K. Padhi, V. Manivannan, J.B. Goodenough, J. Electrochem. Soc., 145 (1998) 1518-1520.

[7] S. Okada, K.S. Nanjundaswamy, A. Manthiram, J.B. Goodenough, H. Ohtsuka, H. Arai and J. Yamaki, Presented at the $36^{\text {th }}$ Power Sources Conference, June 6-9, 1994.

[8] S. Patoux, PhD thesis, Université de Picardie Jules Verne, France (2003).

[9] S. Denis, PhD thesis, Université de Picardie Jules Verne, France (1998).

[10] P. Poizot, PhD thesis, Université de Picardie Jules Verne, France (2001).

[11] P. Poizot, S. Laruelle, M. Touboul and J.-M. Tarascon, C.R. Chimie, 6 (2003) 125-134.

[12] M. Dollé, S. Patoux and T.J. Richardson, J. Power Sources, 144 (2005).208-213.

[13] G. Rousse, J. Rodrìguez-Carvajal, S. Patoux and C.Masquelier, Chem. Mater., 15 (2003) $4082-4090$.

[14]WinPLOTR software downloadable at: http://www-llb.cea.fr/fullweb/winplotr/winplotr.htm.

[15] J. Muller and J.C. Joubert, J. Solid State Chem., 14 (1975) 8-13.

[16] L. Levinson and B.M. Wanklyn, J. Solid State Chem., 3 (1971) 131-133.

[17] B. Robertson and E. Kostiner, J. Solid State Chem., 4 (1972) 29-37.

[18] E. Baudrin, S. Denis, F. Orsini, L. Seguin, M. Touboul and J.-M. Tarascon, J. Mater. Chem., 9 (1999) 101-105.

[19] X. Wang, K.R. Heier, C.L. Stern and K.R. Poeppelmeier, Inorg. Chem., 37 (1998) 69216927.

[20] P. Poizot, S. Laruelle, M. Touboul, M. Louër and D. Louër, J. Mater. Chem., 10 (2000) $1841-1845$. 
[21] S. Denis, E. Baudrin, F. Orsini, G. Ouvrard, M. Touboul and J.-M. Tarascon, J. Power Sources, 81-82 (1999) 79-84.

[22] S. Denis, R. Dedryvère, E. Baudrin, S. Laruelle, M. Touboul, J. Olivier-Fourcade, J.C. Jumas and J.-M. Tarascon, Chem. Mater., 12 (2000) 3733-3739.

[23] P. Poizot, E. Baudrin, S. Laruelle, L. Dupont, M. Touboul and J.-M. Tarascon, Solid State Ionics, 138 (2000) 31-40.

[24] M. Hayashibara, M. Eguchi, T. Miura and T. Kishi, Solid State Ionics, 98 (1997) 119-125.

[25] M.A. Lafontaine, J.M. Grenéche, Y. Laligant and G. Férey, J. Solid State Chem., 108 (1994) $1-10$.

[26] D. Ilic and D. Neumann, J. Power Sources, 43-44 (1993) 589-593.

[27] M. Morcrette, P. Rozier, L. Dupont, E. Mugnier, M. Sannier, J. Galy and J.-M. Tarascon, Nature Mater., 2 (2003) 755-761 and M. Morcrette, P. Rozier, L. Dupont, D. Larcher, S. Laruelle, S. Grugeon, P. Poizot and J.-M. Tarascon, Abs. 15 of the $12^{\text {th }}$ IMLB at Nara, Japan (2004).

[28] P. Schmid-Beurmann, J. Mater. Chem., 11 (2001) 660-667.

[29] C. Masquelier, A.K. Padhi, K.S. Nanjundaswamy and J.B. Goodenough, J. Solid State Chem., 135 (1998) 228-234.

[30] C. Wurm, M. Morcrette, G. Rousse, L. Dupont and C. Masquelier, Chem. Mater., 14 (2002) 2701-2710.

[31] C. Masquelier, P. Reale, C. Wurm, M. Morcrette, L. Dupont and D. Larcher, J. Electrochem. Soc., 149 (2002) 1037-1044.

[32] P. Reale, B. Scrosati, C. Delacourt, C. Wurm, M. Morcrette and C. Masquelier, Chem. Mater., 15 (2003) 5051-5058 
[33] Y. Song, S. Yang, P.Y. Zavalij and M.S. Whittingham, Mater. Res. Bull., 37 (2002) 12491257.

[34] Y. Song, P.Y. Zavalij, M. Suzuki and M.S. Whittingham, Inorg. Chem., 41 (2002) 57785786.

[35] J.L.C. Rowsell, J. Gaubicher and L.F. Nazar, J. Power Sources, $97-98$ (2001) 254-257.

[36] A. Nytén, A. Abouimrane, M. Armand, T. Gustafsson and J.O. Thomas, Electrochemistry Communications, 7 ( 2005)156-160 
Table 1. Theoretical and experimental capacities of various iron(III)-based polyanionic structure materials in lithium cells, for a lower limit voltage fixed at $2 \mathrm{~V} \mathrm{vs.} \mathrm{Li}^{+} / \mathrm{Li}$.

\begin{tabular}{|c|c|c|c|c|c|}
\hline Compound & V vs. $\mathrm{Li}^{+} / \mathrm{Li}$ & $\begin{array}{l}\text { Theor. Capacity } \\
(\mathrm{mAh} / \mathrm{g} \text { per e } \\
\text { mole })\end{array}$ & $\begin{array}{l}\text { Theor. number of } \\
\mathrm{e}^{-} \quad \text { moles } \\
\text { exchanged }^{\text {(a) }}\end{array}$ & $\begin{array}{l}\text { Exp. Capacity } \\
(\mathrm{mAh} / \mathrm{g}), \text { Rate }\end{array}$ & Ref. \\
\hline $\mathrm{FeVO}_{4}-\mathrm{I}$ & $2.8-2.2$ & 156.9 & 2 & $160(\mathrm{C} / 20)$ & [24], [22] \\
\hline $\mathrm{Fe}_{2} \mathrm{~V}_{4} \mathrm{O}_{13}$ & $3.4-2.0$ & 51.2 & 6 & $205(\mathrm{C} / 10)$ & This work \\
\hline $\mathrm{Fe}_{4}\left(\mathrm{~V}_{2} \mathrm{O}_{7}\right)_{3} \cdot 3 \mathrm{H}_{2} \mathrm{O}$ & $3.2-2.0$ & 29.2 & 10 & $193(\mathrm{C} / 5)$ & This work \\
\hline$\beta-\mathrm{Cu}_{3} \mathrm{Fe}_{4}\left(\mathrm{VO}_{4}\right)_{6}$ & $3.2-2.0$ & 24.3 & 16 & $243(\mathrm{C} / 5)$ & This work \\
\hline $\mathrm{NaCuFe}_{2}\left(\mathrm{VO}_{4}\right)_{3}$ & $3.2-2.0$ & 49.4 & 7 & $193(\mathrm{C} / 5)$ & This work \\
\hline $\mathrm{Fe}\left(\mathrm{PO}_{3}\right)_{3}$ & $\sim 2.8$ & 91.5 & 1 & $<10(\mathrm{C} / 50)$ & This work \\
\hline $\mathrm{Fe}_{3} \mathrm{O}_{3} \mathrm{PO}_{4}$ & 2.2 & 86.3 & 3 & $43(\mathrm{C} / 50)$ & This work \\
\hline $\mathrm{FePO}_{4}$-quartz & $\sim 2.8$ & 177.7 & 1 & $45(\mathrm{C} / 50)$ & This work, [33] \\
\hline $\mathrm{FePO}_{4}$-heterosite & 3.45 & 177.7 & 1 & $150-160(\mathrm{C} / 50)$ & This work, $[8]$ \\
\hline $\mathrm{Fe}_{4}\left(\mathrm{P}_{2} \mathrm{O}_{7}\right)_{3}$ & $\sim 2.8$ & 36.0 & 4 & $85(\mathrm{C} / 12.5)$ & This work, [31] \\
\hline $\mathrm{Fe}_{1.2} \mathrm{PO}_{4} \mathrm{X}^{(\mathrm{b})}$ & $3.1-2.4$ & 148.2 & 1.2 & $160(\mathrm{C} / 20)$ & This work, [12] \\
\hline $\mathrm{A}-\mathrm{Fe}_{2}\left(\mathrm{MoO}_{4}\right)_{3}$ & 3.0 & 45.3 & 2 & $90(\mathrm{C} / 10)$ & {$[8]$} \\
\hline $\mathrm{A}-\mathrm{Fe}_{2}\left(\mathrm{SO}_{4}\right)_{3}$ & 3.6 & 67.0 & 2 & $110(\mathrm{C} / 10)$ & {$[8]$} \\
\hline $\mathrm{B}-\mathrm{Fe}_{2}\left(\mathrm{SO}_{4}\right)_{3}$ & 3.6 & 67.0 & 2 & $120(\mathrm{C} / 10)$ & {$[8]$} \\
\hline $\mathrm{FeBO}_{3}$ & $<2(1.2)$ & 233.7 & 1 & $\sim 0$ & {$[35]$} \\
\hline $\mathrm{Fe}_{3} \mathrm{BO}_{6}$ & $<2(1.4)$ & 97.7 & 3 & $\sim 0$ & [35] \\
\hline
\end{tabular}

(a) Based on the $\mathrm{Fe}^{3+} / \mathrm{Fe}^{2+}, \mathrm{V}^{5+} / \mathrm{V}^{4+}$ and $\mathrm{Cu}^{2+} / \mathrm{Cu}^{0}$ redox couples (other redox couples, like $\mathrm{V}^{4+} / \mathrm{V}^{3+}$, may however be also active).

(b) $\mathrm{X}=\mathrm{F}_{0.11}(\mathrm{OH})_{0.46}\left(\mathrm{H}_{2} \mathrm{O}\right)_{0.43}$ 
Table 2.Unit cell parameters of various iron vanadates compounds, obtained from Full Pattern Matching refinements.

\begin{tabular}{lcccccccc} 
Compound & S.G. & $\mathrm{Z}$ & $\mathrm{a}(\AA)$ & $\mathrm{b}(\AA)$ & $\mathrm{c}(\AA)$ & $\alpha\left(^{\circ}\right)$ & $\beta\left(^{\circ}\right)$ & $\gamma\left({ }^{\circ}\right)$ \\
\hline $\mathrm{FeVO}_{4} \mathrm{I}$ & $\mathrm{P} \overline{1}$ & 6 & $6.710(1)$ & $8.055(1)$ & $9.345(1)$ & $96.66(1)$ & $106.66(1)$ & $101.53(1)$ \\
\hline $\mathrm{Fe}_{2} \mathrm{~V}_{4} \mathrm{O}_{13}$ & $\mathrm{P}{ }_{1} / \mathrm{c}$ & 4 & $8.309(1)$ & $9.397(1)$ & $14.570(2)$ & 90 & $102.29(1)$ & 90 \\
\hline $\mathrm{Fe}_{4}\left(\mathrm{~V}_{2} \mathrm{O}_{7}\right)_{3} \cdot 3 \mathrm{H}_{2} \mathrm{O}$ & $\mathrm{P} 2_{1} 2_{1} 2_{1}$ & 4 & $11.972(2)$ & $9.485(1)$ & $8.332(1)$ & 90 & 90 & 90 \\
\hline$\beta-\mathrm{Cu}_{3} \mathrm{Fe}_{4}\left(\mathrm{VO}_{4}\right)_{6}$ & $\mathrm{P} \overline{1}$ & 1 & $6.586(1)$ & $8.034(1)$ & $9.730(1)$ & $105.96(1)$ & $103.74(1)$ & $102.23(1)$ \\
\hline $\mathrm{NaCuFe}_{2}\left(\mathrm{VO}_{4}\right)_{3}$ & $\mathrm{P} \overline{1}$ & 2 & $8.222(2)$ & $9.805(2)$ & $6.650(1)$ & $103.57(1)$ & $102.02(2)$ & $106.99(2)$
\end{tabular}




\section{Figure Captions}

1. GITT potential-composition profiles of a) $\mathrm{FeVO}_{4}$ (type-I), b) $\mathrm{Fe}_{2} \mathrm{~V}_{4} \mathrm{O}_{13}$ and c) $\mathrm{Fe}_{4}\left(\mathrm{~V}_{2} \mathrm{O}_{7}\right)_{3} \cdot 3 \mathrm{H}_{2} \mathrm{O}$ at $\mathrm{C} / 20$ (per mole $\mathrm{Fe}$ ) for $30 \mathrm{~min}$ followed by $30 \mathrm{~min}$ rest.

2. Potential-capacity profiles of the $1^{\text {st }}, 10^{\text {th }}$ and $20^{\text {th }}$ discharges of $\mathrm{Fe}_{2} \mathrm{~V}_{4} \mathrm{O}_{13} / \mathrm{Li}$ cycled at $\mathrm{C} / 5$ rate. Inset: discharge and charge capacities as a function of cycle number.

3. Structures of $\mathrm{Fe}_{6}\left(\mathrm{VO}_{4}\right)_{6}, \mathrm{Fe}_{4}\left(\mathrm{VO}_{4}\right)_{6}$ and $\beta-\mathrm{Cu}_{3} \mathrm{Fe}_{4}\left(\mathrm{VO}_{4}\right)_{6}: \mathrm{FeO}_{6}$ octahedra dark-filled, $\mathrm{VO}_{4}$ tetrahedra light-filled, $\mathrm{CuO}_{5}$ and $\mathrm{CuO}_{6}$ polyhedra outlined.

4. GITT potential-composition profiles of a) $\beta-\mathrm{Cu}_{3} \mathrm{Fe}_{4}\left(\mathrm{VO}_{4}\right)_{6}$ and b) $\mathrm{NaCuFe}_{2}\left(\mathrm{VO}_{4}\right)_{3}$.

5. Discharge capacity as a function of cycle number for $\beta-\mathrm{Cu}_{3} \mathrm{Fe}_{4}\left(\mathrm{VO}_{4}\right)_{6} / \mathrm{Li}$ cells, charged and discharged at various rates, between 3.6 and $2.0 \mathrm{~V}$.

6. Ex situ X-ray diffraction patterns of $\beta-\mathrm{Cu}_{3} \mathrm{Fe}_{4}\left(\mathrm{VO}_{4}\right)_{6}$ electrode as prepared, after discharge to 2.0 V vs. $\mathrm{Li}^{+} / \mathrm{Li}$, after one complete cycle, and after 25 full cycles.

7. GITT potential-composition profiles of a) $\mathrm{Fe}\left(\mathrm{PO}_{3}\right)_{3}$, b) $\left.\mathrm{Fe}_{3} \mathrm{O}_{3} \mathrm{PO}_{4}, \mathrm{c}\right) \mathrm{FePO}_{4}$ (quartz), d) $\mathrm{FePO}_{4}$ (heterosite), e) $\mathrm{Fe}_{4}\left(\mathrm{P}_{2} \mathrm{O}_{7}\right)_{3}$ and $\left.\mathrm{f}\right) \mathrm{Fe}_{1.2} \mathrm{PO}_{4} \mathrm{X}\left(\mathrm{X}=\mathrm{F}_{0.11}(\mathrm{OH})_{0.46}\left(\mathrm{H}_{2} \mathrm{O}\right)_{0.43}\right)$. 

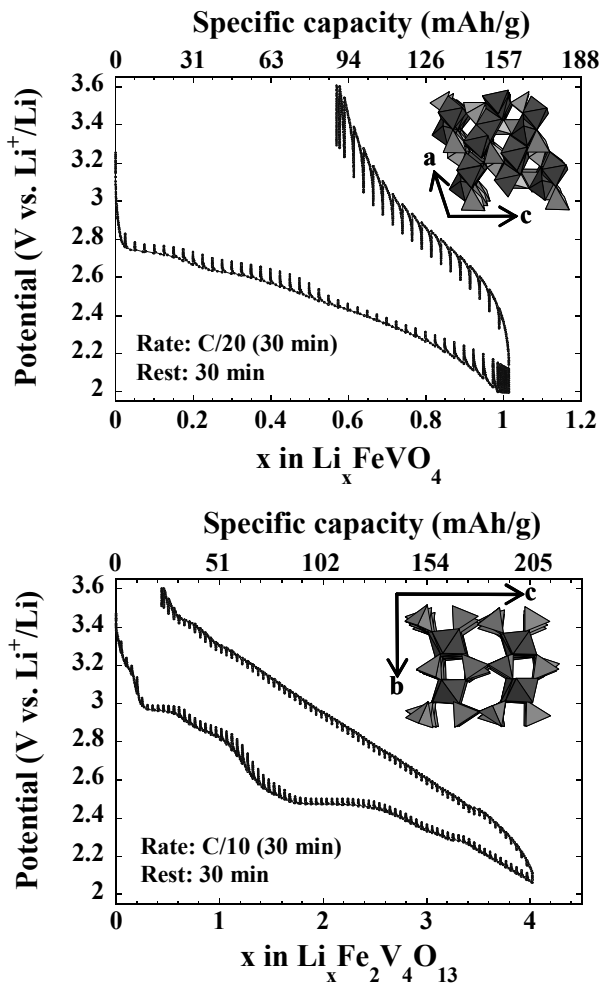

Specific capacity $(\mathrm{mAh} / \mathrm{g})$

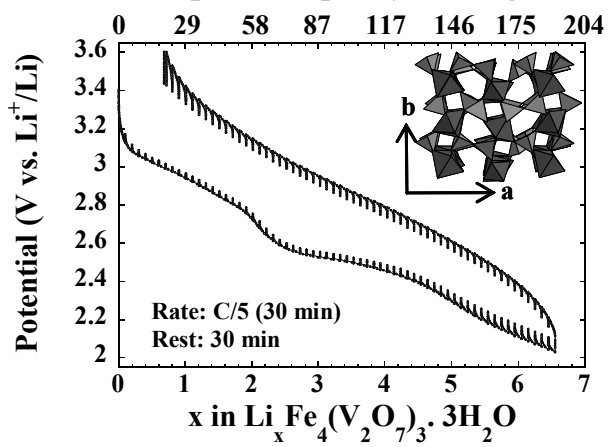

Figure 1. GITT potential-composition profiles of a) $\mathrm{FeVO}_{4}$ (type-I), b) $\mathrm{Fe}_{2} \mathrm{~V}_{4} \mathrm{O}_{13}$ and c) $\mathrm{Fe}_{4}\left(\mathrm{~V}_{2} \mathrm{O}_{7}\right)_{3} \cdot 3 \mathrm{H}_{2} \mathrm{O}$ at $\mathrm{C} / 20$ (per mole $\mathrm{Fe}$ ) for $30 \mathrm{~min}$ followed by 30 min rest. 


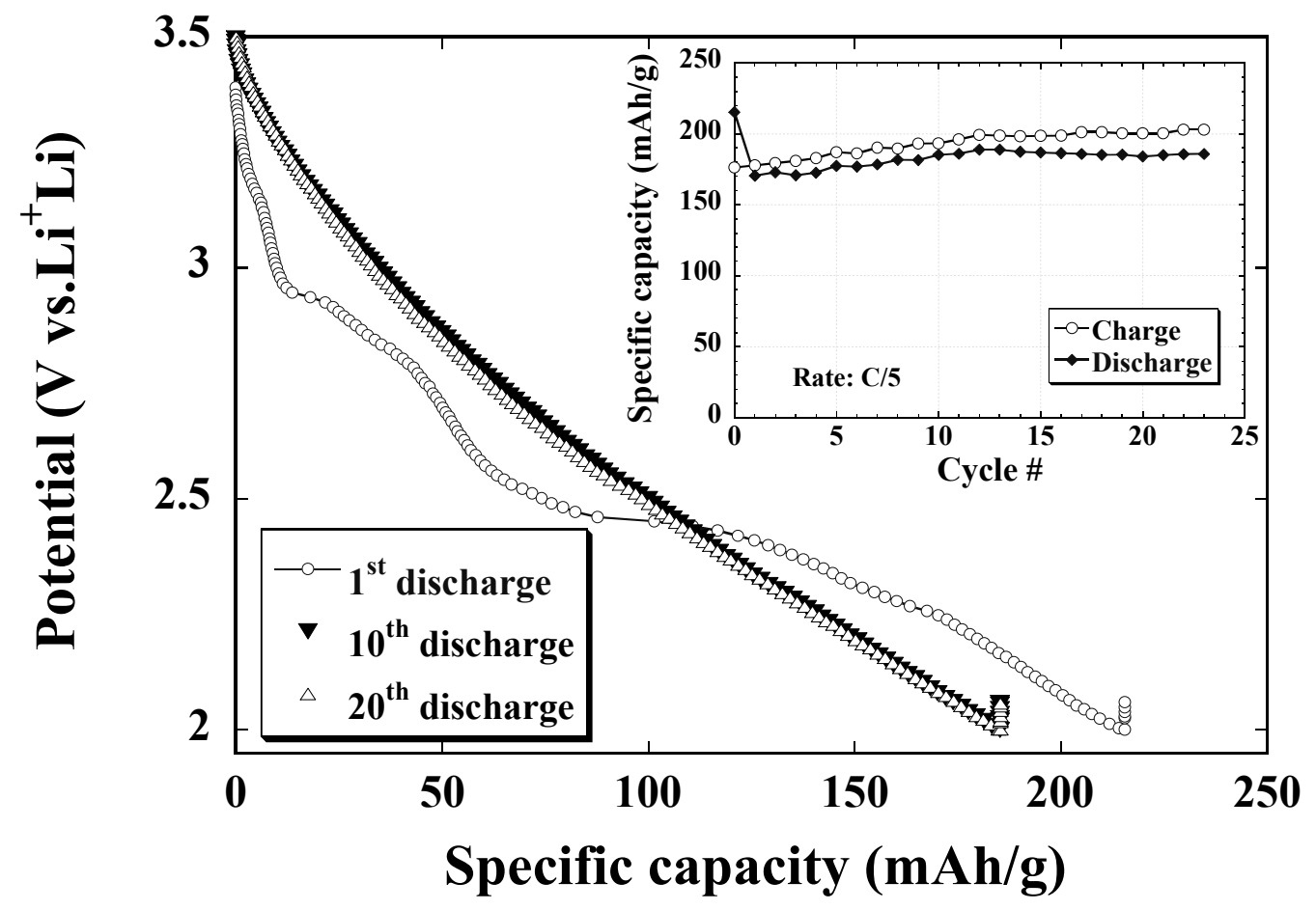

Figure 2. Potential-capacity profiles of the $1^{\text {st }}, 10^{\text {th }}$ and $20^{\text {th }}$ discharges of $\mathrm{Fe}_{2} \mathrm{~V}_{4} \mathrm{O}_{13} / \mathrm{Li}$ cycled at $\mathrm{C} / 5$ rate. Inset: discharge and charge capacities as a function of cycle number. 

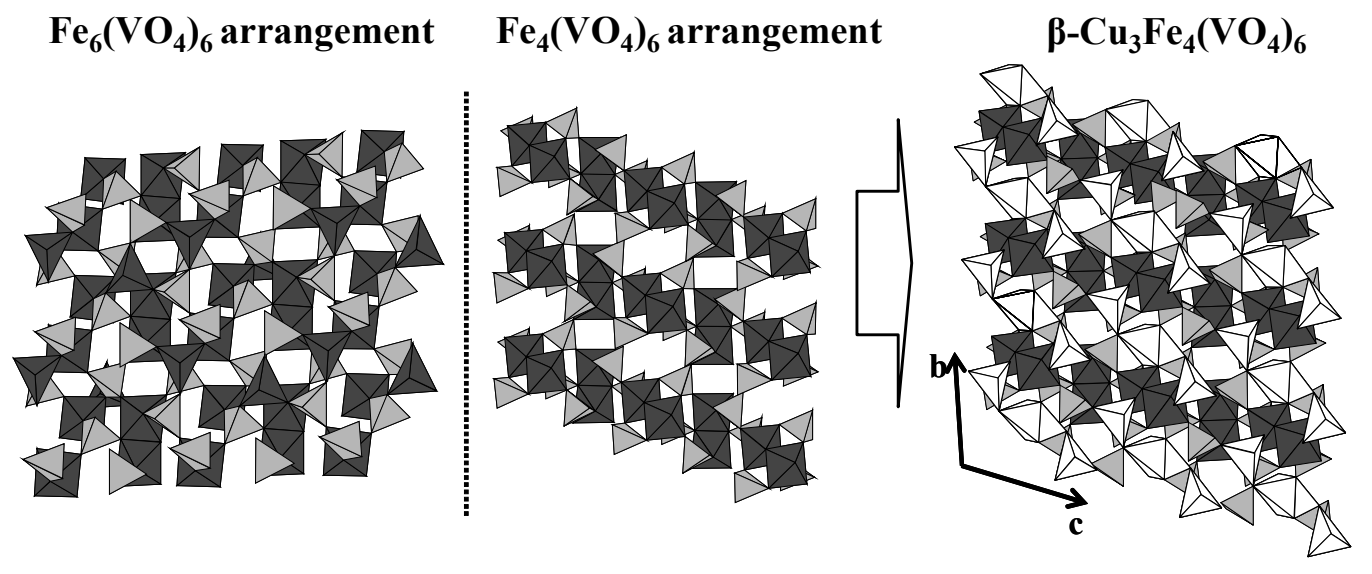

Figure 3. Structures of $\mathrm{Fe}_{6}\left(\mathrm{VO}_{4}\right)_{6}, \mathrm{Fe}_{4}\left(\mathrm{VO}_{4}\right)_{6}$ and $\beta-\mathrm{Cu}_{3} \mathrm{Fe}_{4}\left(\mathrm{VO}_{4}\right)_{6}: \mathrm{FeO}_{6}$ octahedra dark-filled, $\mathrm{VO}_{4}$ tetrahedra lightfilled, $\mathrm{CuO}_{5}$ and $\mathrm{CuO}_{6}$ polyhedra outlined. 

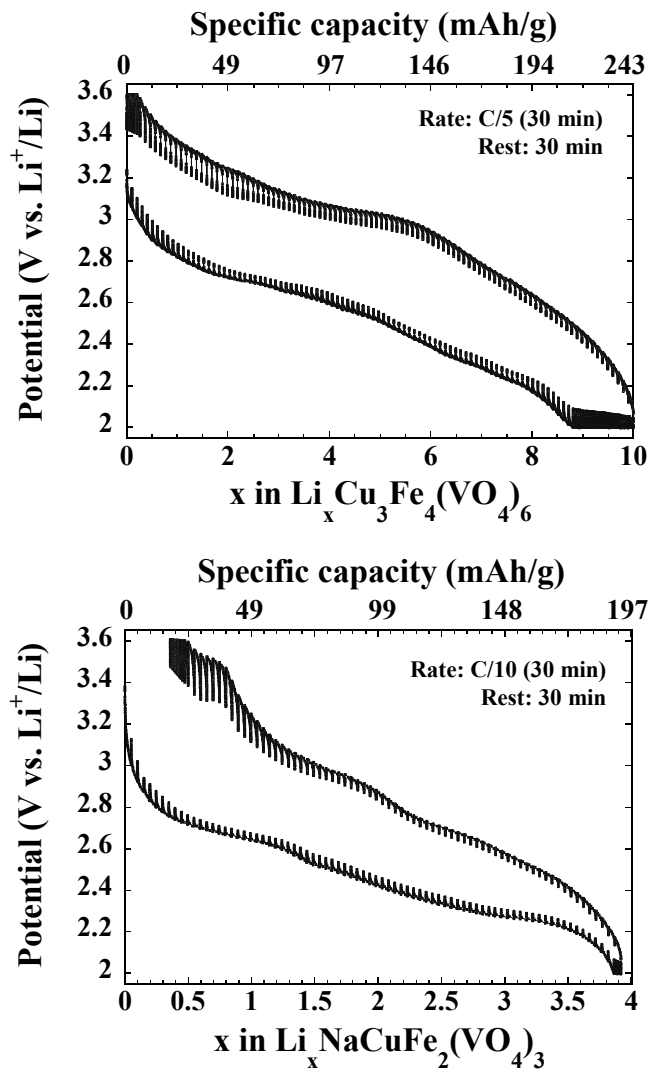

Figure 4. GITT potential-composition profiles of a) $\beta-\mathrm{Cu}_{3} \mathrm{Fe}_{4}\left(\mathrm{VO}_{4}\right)_{6}$ and b) $\mathrm{NaCuFe}_{2}\left(\mathrm{VO}_{4}\right)_{3}$. 


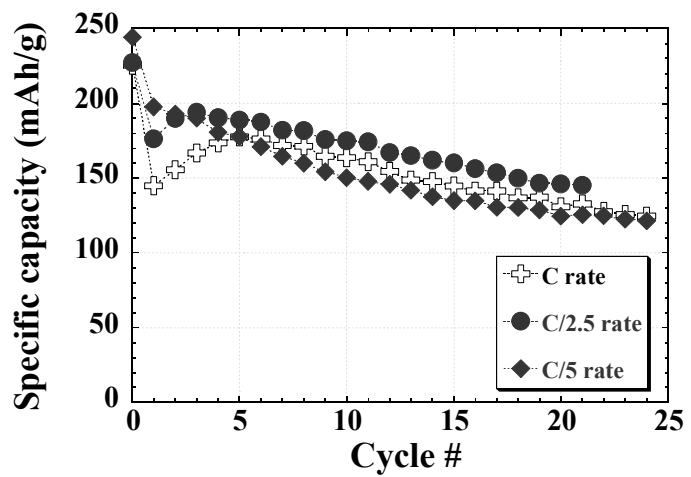

Figure 5. Discharge capacity as a function of cycle number for $\beta-\mathrm{Cu}_{3} \mathrm{Fe}_{4}\left(\mathrm{VO}_{4}\right)_{6} / \mathrm{Li}$ cells, charged and discharged at various rates, between 3.6 and $2.0 \mathrm{~V}$. 


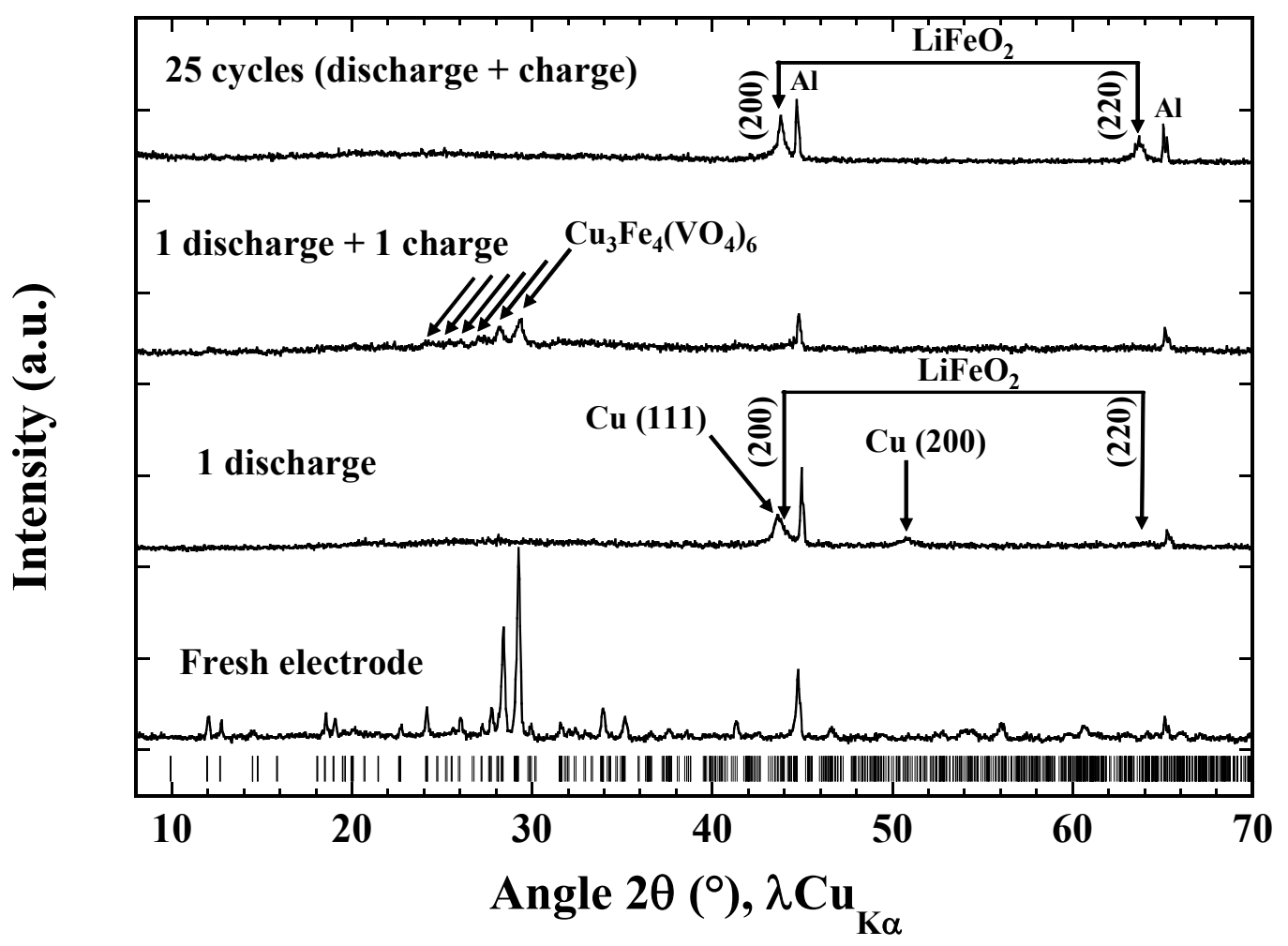

Figure 6. Ex situ X-ray diffraction patterns of $\beta-\mathrm{Cu}_{3} \mathrm{Fe}_{4}\left(\mathrm{VO}_{4}\right)_{6}$ electrode as prepared, after discharge to $2.0 \mathrm{~V}$ vs. $\mathrm{Li}^{+} / \mathrm{Li}$, after one complete cycle, and after 25 full cycles. 

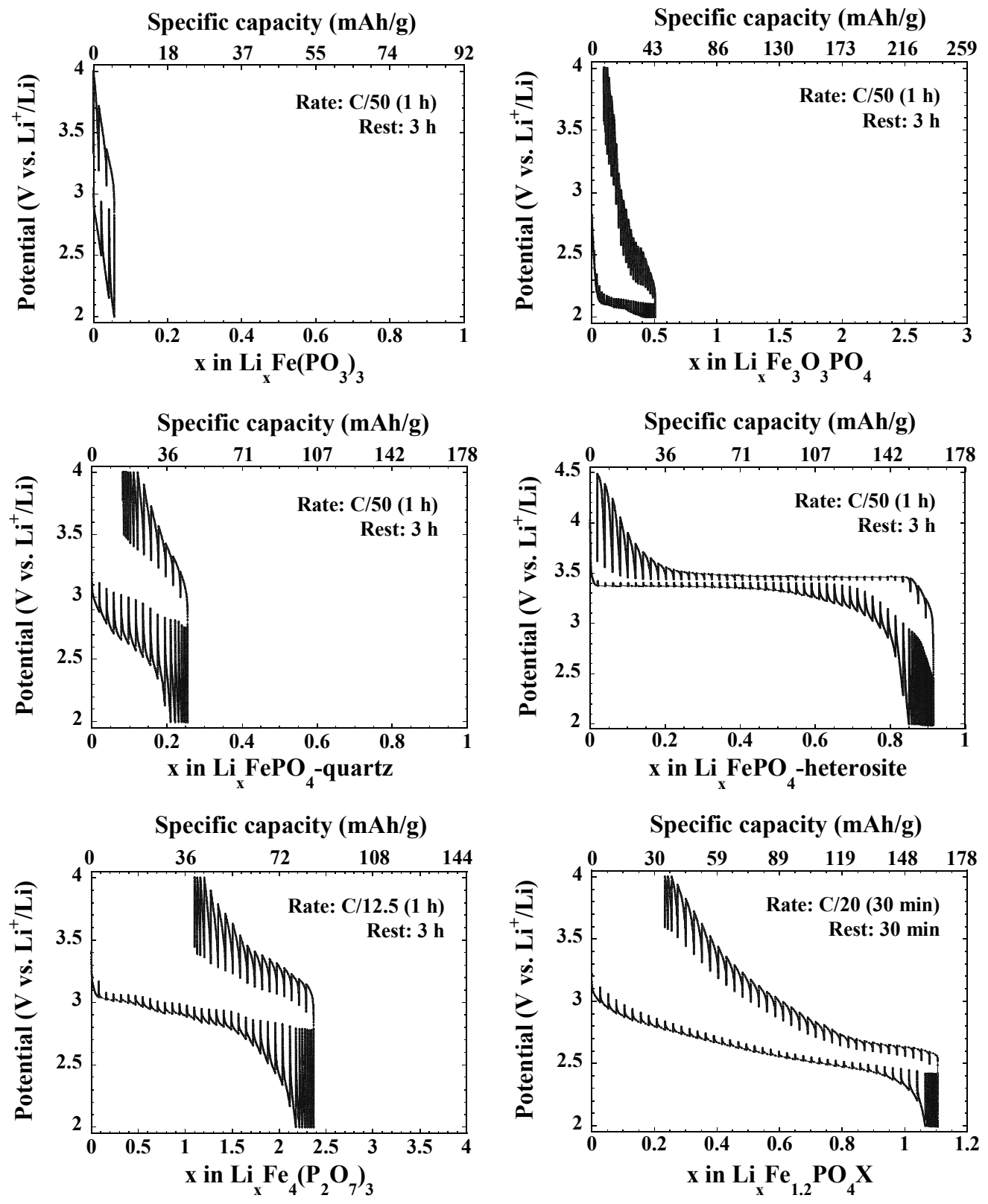

Figure 7. GITT potential-composition profiles of a) $\mathrm{Fe}\left(\mathrm{PO}_{3}\right)_{3}$, b) $\mathrm{Fe}_{3} \mathrm{O}_{3} \mathrm{PO}_{4}$, c) $\mathrm{FePO}_{4}$ (quartz), d) $\mathrm{FePO}_{4}$ (heterosite), e) $\mathrm{Fe}_{4}\left(\mathrm{P}_{2} \mathrm{O}_{7}\right)_{3}$ and f) $\mathrm{Fe}_{1.2} \mathrm{PO}_{4} \mathrm{X}\left(\mathrm{X}=\mathrm{F}_{0.11}(\mathrm{OH})_{0.46}\left(\mathrm{H}_{2} \mathrm{O}\right)_{0.43}\right)$. 